\title{
When the Shepherd Becomes the Wolf: What is wrong with the Independent National Electoral Commission of Nigeria?
}

\author{
A.O. Enabulele (corresponding author) \\ Department of Jurisprudence and International Law, Faculty of Law, University of Benin \\ Nigeria (Ph.D Candidate, Brunel University, Uxbridge, Middlesex, UB8 9PH) \\ Tel: 44-782-732-3139 E-mail: Amos.Enabulele@brunel.ac.uk.
}

A.O. Ewere

Department of Private and Property Law, Faculty of Law, University of Benin

Benin City, Nigeria

Tel: 23-480-3091-4016 E-mail: gentleosaro@yahoo.co.uk.

\begin{abstract}
The strategic position Nigeria occupies in the West Africa sub-region and in Africa at large is largely reflected in the size of its population; its political influence and economic potentials. For these reasons, peace and stability in Nigeria, naturally reflects in Africa, particularly, in West Africa. Since the current democratic governance began in 1999, Nigerians have looked towards each general election with trepidation due to the unhealthy signals emerging from political activities supervised by the Independent National Electoral Commission (INEC). With each general election - 1999, 2003 and 2007 - the polity is highly heated up by threats of violence and destruction. Words like the "country will burn if ...," "the masses of this country will revolt if ...." INEC, being the 'if' factor. INEC has since 1999, progressively shown itself as a body incapable of abiding by law and or upholding fairness and non-partisanship in the discharge of its constitutional duties. Opposition politicians and indeed the voters conclude even before elections are held that INEC would manipulate the votes in favour of its preferred political party, and thus begin to look for ways and means - including violent protests - of defending their votes.

This work highlights the failures of INEC, not from the authors' subjective perspective, but from facts and figures gathered from decided cases and the views expressed in those cases. The work discusses these failures; it also discusses the possible reasons for the weaknesses of INEC as well as proposed solutions.
\end{abstract}

Keywords: Independent National Electoral Commission, Rule of Law

\section{Introduction}

There is a general consensus on the virtues of a good shepherd: a good shepherd must at all times keep a watchful eye on the sheep; the shepherd must minister to their needs and be ready, even, to lay down his life to defend the sheep against its most formidable enemy, the wolf. Where the shepherd becomes a wolf, the sheep becomes defenceless and vulnerable to all sorts of dangers.

The use of the shepherd and the wolf here is symbolic; both terms are consciously used to represent the Independent National Electoral Commission (INEC) in its relation with the sheep of its pasture, the electoral process in Nigeria. INEC is the Commission saddled with the responsibility of overseeing all electoral processes in Nigeria. It is the body empowered by law to guard the political conscience of the Nigerian people against ruthless politicians and undemocratic political associations and guide it towards the entrenchment of a lasting democratic culture. But rather, INEC has become nothing but the instrument with which politicians have let loose their dogs of vandalism and death upon the very political process it was set up by law to nurture, protect and preserve. It has constituted itself into a self-serving organization; a political party of sorts, which flagrantly displays its support for preferred candidates in both intra and inter party contests.

The wolfish attitude of INEC was glaringly brought to the fore during the concluded 2007 general elections and the subsequent re-runs, ordered by the courts. There are overwhelming evidence from the courts that INEC openly descended into the arena of political rivalry and took sides with its preferred candidates in intra party contests and its preferred political party in inter part contests, and thus became blinded by its desire to ensure victory for such candidates at all cost and against all known democratic values it was established by law to nurture. Despite the various concerns expressed in very strong words by the courts and the admission of 
President Umaru Yar' Adua himself, that the election was flawed (note 1), INEC has persistently carried on like an organization not bound by law: a situation which led to the judicial determination of over eighty percent of the results it declared in the 2007 rounds of elections, even to the extent that some of the cases are still pending in court less than a year to the next general elections in the country. In a manner reminiscent of the pre 2007 elections, it has continued on the same path as the 2011 general elections approach - all the indexes of a biased institution, which was displayed by INEC during the pre-election era of the 2007 elections have continued unabated: from the role being played in the crises rocking the All Progressive Grand Alliance (note 2) to the role it is playing in the court cases in which the illegality it freely engaged in during the 2007 elections and beyond, the prognosis is clear - the present INEC is not in a hurry to quit playing the wolf. The negative effects of the unhealthy activities of INEC are all too evident in the manner the electoral process in the country has continued to slide toward an anarchic system not anchored on law.

It is common knowledge that the validity of all the presidential elections conducted by INEC since 1999 has been contested up to the Supreme Court. What many have failed to realize is the fact that the decline of the electoral system is also reflected in the banters the elections have received from the Justices of the court. In the 1999 presidential election petition - Falae v. Obasanjo (Note 3) - the Supreme Court unanimously endorsed the victory of the respondent; in 2003 - Buhari v. Obasanjo (Note 4) - the Supreme Court also affirmed the election but that decision did not receive the unanimity of all the Justices like the previous one, as one of the Justices, Nsofo JSC condemned the election in very strong words; in 2007 - Abubakar v. Yar' Adua (Note 5) and Buhari v INEC (Note 6) the Supreme Court also affirmed the election but this time by a slight majority, as three out of the seven Justices of the court dissented. Also there is hardly one of the results of over eight hundred offices for which INEC conducted elections which was not challenged in court, and like never before in the history of Nigeria have so many results from a particular round of election been nullified by the courts. (Note 7) What is more, the rerun elections in Kogi, Ekiti, Bayelsa, Cross River States, among others, were also marred by the unrepentant INEC, as some of these reruns are also being challenged in court.

This declining situation did not escape the notice of the European Union Monitoring Team. The Head of the European Union Monitoring team and member of the European Parliament, Max van den Berg, while speaking with the BBC, asserted that the 2007 elections,... was one of the worst elections that the EU had observed... I can compare it with 2003, when I was the chief observer, and I had expected, really, after that was a very disappointing election, that we would see now something better. But we have not seen that, and the credibility is not there... The whole thing was not at all living up to the hopes of the Nigerian people, chaotic, and I would say it left them behind, demoralized. (Sic) (Note 8)

In the same vein, the European Union Election Observation Mission (EUEOM) which deployed over 150 observers from $21 \mathrm{EU}$ member states lamented that:

The 2007 state and federal elections have fallen far short of basic international and regional standards for democratic elections. They were marred by poor organization, lack of essential transparency, widespread procedural irregularities, significant evidence of fraud, particularly during the result collation process, voters' disenfranchisement at different stages of the process, lack of equal conditions for contestants and numerous incidents of violence. As a result, the elections have not lived up to the hopes and expectations of the Nigerian people and the process cannot be considered to have been credible. (Note 9)

Also, in the opinion of the US-based International Republican Institute,

The entire electoral process had failed to meet international standards... Nigerian election process...falls below the standards which Nigeria itself has set in previous elections and also falls below international standards witnessed by IRI and members of this delegation throughout the world... (Note 10)

As the 2011 general elections approach, the activities of present INEC does not give room for any optimism; all evidence emanating from the courts and political activities supervised by INEC do not only show a clear disconnect between the present INEC and the functions it was set up by the constitution to perform, but also reveal an INEC that is totally committed to its old ways of truncating the rule of law and derailing the current democratic experiment in the country. What is equally worrisome is the indifference of the PDP-led government on the activities of INEC, particularly the contempt with which the current INEC has continued to treat judgments which are adverse to its preferred candidates, irrespective of the wishes of the people expressed through the ballot boxes provided and supervised by INEC with tax payers' money. The clear implication of the partiality of INEC is not only that Nigerian voters are becoming increasingly and dangerously estranged from the ballot box, but also that opposition political parties and their candidates no longer look up to INEC but to the already over-burdened courts, for the counting and recounting of votes towards the declaration of results that will reflect the actual votes. (Note 11) This is not restricted to inter party contests alone, as there is also the trend of 
politicians who rely on the courts to maintain their actual positions in intra party contests, for the nomination of candidates or election of party officers. (Note 12)

Given the important role INEC has been established by the constitution to perform and the high premium the Nigerian people place on democratic governance, this article seeks to draw attention to the role being played by the present INEC in the light of the views expressed by the courts and to endeavour to determine the possible causes of the lapses being displayed by INEC - are the lapses the result of institutional failure or inadequacy of legal protection? Could it be corruption? As Nigeria matches towards another set of elections in 2011, the importance of a study of this nature cannot be overemphasized particularly now that the voters are becoming more aware of the link between a free and fair election and good governance. The high rate at which the awareness, which began to manifests in 2003, grew in 2007, shows that the people (voters) will less likely be willing to accept manipulated election results, as they were during previous elections. That being the case, electoral violence and its attendant loss of lives and properties - such as we saw in Plateau, Ekiti and Kogi States - will be inevitable, if immediate steps are not taken to address the shortcomings of INEC.

\section{The Independent National Electoral Commission (INEC)}

INEC was established by section 153 of the 1999 Constitution and section 1 of the Electoral Act 2006, as a body corporate with perpetual succession, capable of suing and being sued in its name. Beyond the addition of 'independence' to the name of the commission, it is an appendage of the executive, which appoints its officers (Note 13) and funds it, as one of its agencies; (Note 14) notwithstanding the provision that INEC shall not be subject to the direction or control of any other authority or person.(Note 15 )

Its functions are provided for in section 15 of Part 1 of the Third Schedule to the constitution, which states that INEC shall have power to -

(a) organize, undertake and supervise all elections to the offices of the President and Vice President, the Governor and Deputy Governor of a State, and to the membership of the Senate, the House of Representatives and the House of Assembly of each State of the Federation;

(b) register political parties in accordance with the provisions of this constitution and an Act of the National Assembly;

(c) monitor the organization and operation of the political parties, including their finances;

(d) arrange for annual examination of auditing of the funds and accounts of political parties, and publish a report on such examination and audit for public information;

(e) arrange and conduct the registration of persons qualified to vote and prepare, maintain and revise the register of voters for the purpose of any election under this constitution;

(f) monitor political campaigns and provide rules and regulations which shall govern political parties;

(g) ensure that all electoral commissioners, electoral and returning officers take and subscribe to the oath of office prescribe by law; ...

Further to this, section 2 of the Electoral Act 2006 provides that in addition to the functions conferred by the constitution, INEC shall have power to:

(a) conduct civic registration;

(b) promote knowledge of sound democratic election processes ...

It is clear from the foregoing that the main function of INEC is to organize, undertake and supervise all elections to the offices of the President and Vice President, the Governor and Deputy-Governor of a State, and to the membership of the Senate, the House of Representatives and House of Assembly of each State of the Federation. It is the only body capable of declaring the result of elections (Note 16) and issuing certificates of return to the victorious candidates. It is, "the official body responsible for the conduct of elections ... [which]... denotes the process of accreditation, voting, collation, recording on all relevant INEC forms and declaration of results. In other words, INEC is the competent authority to conduct an election and issue results."(Note 17)

There is therefore no doubt that INEC has enormous decision making powers in the electoral process, and which power must be exercised to add value to the electoral process by encouraging as against discouraging the Nigerian people from fully participating in deciding to whom they intend to entrust their affairs. Due to the premium free societies, the world over, place on the "right of a people to govern themselves",(Note 18) it is important that INEC is well guided by law, else it becomes a wolf that will devour the very sheep of its pasture, the electoral process. (Note 19) 
This perhaps explains why the constitution and the Electoral Act exhaustively provide, at least, the minimum standards to which INEC must conform for its conduct to be valid. Consequently, any inquiry into the propriety or otherwise of any conduct of INEC must commence from the constitution and the Electoral Act provisions on the conduct called into question.

\section{The Shepherd or the Wolf?}

Having discussed the constitutional duties of INEC, we shall now proceed to show from the activities of INEC, particularly as reported in decided cases, that the present INEC has not conducted itself as an organization bound by law to be fair and upright in its dealings. The records are clear - in the performance of its constitutional and statutory duties, INEC has performed far below the expectations of both the passionate and dispassionate observers. We may well take a close look at how INEC has fared in the performance of some of the functions enumerated above as captured by the decisions of the courts from three perspectives - (a) intra party politics; (b) inter party contests; and (c) upholding the rule of law.

\subsection{Intra Party Politics}

The framers of the Nigerian Constitution and the Electoral Act understood that the sustenance of internal democracy within political parties is a pre-requisite for the development of, and the sustenance of democratic contests between political parties. Hence, section 15(d) of Part 1 of the Third Schedule to the constitution gives INEC the overall power to monitor the organization and operation of political parties. An essential corollary of the section 15(d) power of INEC is the duty to provide the necessary checks on political parties in the nomination of their candidates with a view to ensuring that the political parties abide by law and the constitution of the parties. INEC is empowered to provide these checks at several stages, beginning from when the congresses of the parties are held, to the stage that the parties submit the names of their candidates to INEC, which is not bound to accept candidates who emerged undemocratically. For the avoidance of doubt, section 85(1) of the Electoral Act 2006, made it mandatory for all political parties to give INEC a 21 day notice of any convention, congress, conference or meeting convened for the purpose of, inter alia, nominating candidates for elections at all levels. By subsection 86(2), INEC is empowered to attend and monitor such conventions or congresses, even without prior notice to the political party; and by the combined reading of subsections $86(2)$ and (4), it is an offence for any political party to nominate candidates in violation of the "constitution, any other law, guidelines, rules or regulations made pursuant to an Act of the National Assembly". Also, lists of candidates to be fielded by political parties are required to be submitted to INEC within 120 days to the elections and such candidates cannot be changed except cogent and verifiable reasons are supplied to INEC. (Note 20)

With these provisions, it cannot be said that the law did not place a high premium on the installation of internal democracy within the political parties through an unbiased and dispassionate INEC; what can however be said, in view of the crises that have engulfed the nomination of candidates by political parties, is that INEC has woefully failed to appreciate the importance of this task so as to invests it with the seriousness it deserves. All the major political parties have, at one time or the other, been engulfed in intra party controversy arising from undemocratic nomination of candidates. And in all the controversies, perhaps, the ones decided in court, the ignoble roles played by INEC in the whole process were fully highlighted.

The case of Uba v. Ukachukwu, presents a very disturbing scenario; a situation in which INEC connived with a political party to declare election results in favour of candidates, other than the ones presented to the electorates for election. This is highly regrettable. In the case, the appellant as $1^{\text {st }}$ respondent, a member of the Peoples' Democratic Party (PDP), sought the party's nomination to contest the Anambra South Senatorial District seat in 2003. The PDP sent what it termed "original list" of candidates contesting various offices in Anambra State to the $2^{\text {nd }}$ respondent (INEC) and the list contained the appellant's name. Subsequently, another list labeled "substitution list" was forwarded by the PDP and the list contained $1^{\text {st }}$ respondent's name. On the same day the second list was sent, the PDP sent what it called "revalidation list" and the appellant's name was shown as the PDP's candidate for Anambra South Senatorial District. This ignited several court actions by different candidates seeking the recognition of the list containing their names. During the pendency of the suits, elections were held, after which INEC declared the $1^{\text {st }}$ respondent the winner of the election, but INEC subsequently cancelled the candidature of the $1^{\text {st }}$ respondent suo motu, and declared the appellant, who was not a candidate at the election, the winner of the election. The $1^{\text {st }}$ respondent filed a petition at the Election Tribunal. In its judgment, the tribunal found in favour of the $1^{\text {st }}$ respondent. The appellant appealed to the Court of Appeal. While allowing the appeal, the court could not turn a blind eye to the unhealthy role played by INEC in the situation leading to the appeal. Opene, JCA, said: "No doubt, INEC, the $2^{\text {nd }}$ respondent created this confusion resulting to this matter. We must observe that the time has come when INEC must grow up, muster courage, gut and assert itself as an 
independent organisation. If it had written the PDP and given it a dateline to inform it as to which of the two candidates that was the party's candidate, this ugly situation would not have arisen." (Note 21)

In the same vein, Akaahs, JCA remarked in his dissenting judgment:

"I wish to observe that the $2^{\text {nd }}-5{ }^{\text {th }}$ respondents abdicated their responsibilities of being an umpire by ensuring that all parties complied with the requirements of the law on the election and in this particular instance [INEC] allowed the PDP to dictate to it the candidates in whose favour the results of the election should be declared. This ought not to be the case. INEC in fact should act and be seen to be independent of anybody or political party." (Note 22)

Despite the sentiments expressed by the Court of Appeal above, INEC continued to exhibit its high propensity for lawlessness. In Onyekweli v. INEC (Note 23) another opportunity presented itself to the Court of Appeal to, once again, counsel INEC on the need to wake up to its constitutional and statutory responsibilities. In the case, the petitioner/appellant had brought a separate action against the Peoples Democratic Party (PDP) before the Federal High Court challenging the substitution of his name with that of one Mercy Alumona - Isei, as the candidate of PDP in the Ndokwa/Ukuani federal constituency of Delta State for the House of Representatives. The Federal High Court found in his favour and declared the said substitution invalid, not having been done with cogent and verifiable reasons as required by the Electoral Act, 2006. This judgment was not appealed by INEC and Mercy Alumona - Isei. Meanwhile INEC conducted election into the office. After the election, INEC declared results in favour of the PDP without declaring the names of the candidates that took part in the election.

The appellant, afraid that INEC will eventually declare Mercy Alumona - Isei, as the winner of the election, filed a petition at the election petition against INEC seeking a declaration that he was the validly nominated candidate of the PDP and that he is entitled to the certificate of return since his party scored the highest number of votes. Ignoring the pending petition, INEC issued a certificate of return to Mercy Alumona - Isei. Consequently, the appellant filed an application to join Mercy Alumona - Isei, as a respondent to the petition. The Tribunal refused the application and dismissed the petition, hence the appellant's appeal to the Court of Appeal, which is the final court on Election Petitions of this class.

Upholding the case of the appellant, the Court of Appeal noted that two novel situations for which there were no precedent, were raised in the petition - (a) a situation where the party to be joined did not become a person whose election or return was complained of until after the certificate of return was given well after the time to file a petition had expired; (b) a situation where a preemptive action is in form of petition to forestall an undue return. Having so observed, the court remarked that it was compelled to use peculiar means to resolve it, (Note 24) and noted that the non-joinder of the declared winner, Mercy Alumona - Isei, as at the time the petition was filed did not affect the petition, and that the action could survive only against INEC. Consequently, the court ordered INEC to issue certificate of return in respect of Ndokwa/Ukuani Federal Constituency of Delta State, to the appellant. While considering whether the non-joinder of Mercy Alumona-Isei was fatal to the appellant's case, Ogunwumiju, JCA had this to say about INEC: “.... This is a novel situation for which there is no precedent. No one could have anticipated that INEC would engage in flagrant disregard of the Electoral Act...I do not think it was even essential to join the party sought to be joined. She was not the protagonist in this case but INEC who issued an unlawful return. The fact of the existence of an unchallenged judgment of the Federal High Court declaring the appellant as the lawful candidate of the PDP is enough to quash whatever ultra vires act done by INEC after the decision. It only stands to reason. The party sought to be joined is a passive participant who is reaping the fruits of INEC's nefarious decisions and the appellant's labour...." (Note 25)

Also, in Amaechi v. INEC (Note 26) the appellant contested the Peoples Democratic Party (PDP) primaries against seven others for the Governorship election in Rivers State and overwhelmingly emerged the winner of the primaries with 6,527 votes out of a total of 6,575 votes cast. After submitting Amaechi's name to the Independent National Electoral Commission (INEC) the PDP substituted the name with Celestine Omehia, the $2^{\text {nd }}$ respondent, who never took part in the said primary election of the party, without giving cogent and verifiable reasons for the substitution as required by section 34 (2) of the Electoral Act 2006. INEC ratified this illegal act and upheld Omehia's candidature for the governorship election, despite the vehement protest of the appellant and other right thinking persons.

Being aggrieved by the unlawful substitution, Amaechi commenced action at the Federal High Court, Abuja claiming, inter alia, that it is unconstitutional, illegal and unlawful for INEC and the PDP to change his name with that of the $2^{\text {nd }}$ respondent. Following the decisions of the trial court and the Court of Appeal which held that the appellant was properly substituted, the appellant appealed to the Supreme Court. While this action was pending, election was conducted by INEC and the $2^{\text {nd }}$ respondent (Omehia) was sworn in as Governor of Rivers 
State. Declaring the entire process that brought the $2^{\text {nd }}$ respondent to office null and void, the Supreme Court unanimously ordered the $2^{\text {nd }}$ respondent to vacate the office for the appellant to be sworn in.

Deprecating the conduct of INEC Aderemi, JSC, noted that,

"The conduct of the $1^{\text {st }}$ respondent (INEC), to say the least, is a brazen disregard to the institution called "the Judiciary." It is a terrible slap on the face of the law. Must the court of law fold its arms and allow this brazen lawlessness go unchecked? I think not...." (Note 27)

The learned Justice, while emphasizing the need for Judges to do justice in line with well tested principles, continued in relation to INEC:

"The decision to substitute Celestine Omehia for Rotimi Chibuike Amaechi by the $3^{\text {rd }}$ respondent (PDP) during the period of pending gubernatorial election represents a display of very grave display of political rascality and an irresponsible and wanton disrespect for rule of law... The $1^{\text {st }}$ respondent (INEC) by acceding to the request of the $3^{\text {rd }}$ respondent for the substitution has painted a picture of itself as a spineless body who's pre-occupation is dissemination of injustice. It ( $1^{\text {st }}$ respondent) has forgotten or it has thrown into the winds the position carved for it by the constitution of the land - An unbiased umpire...." (Note 28)

What more could be said about a body, saddled with such a crucial task as INEC, which conducts have been so largely condemned by an unbiased and a dispassionate institution, as the judiciary. The status quo which is still largely maintained strikes at the root of democracy in Nigeria.

\subsection{Inter-Party Contests}

What has been said in the preceding segment naturally gives a clue as to what to expect in this segment. How can a body which has been unable to live above board in intra-party contests be able to deal with inter-party contests, which is more competitive and presents a broader range of interest and hence more incentives for disagreements. This is particularly so because the INEC chairman and invariably the other commissioners are expected to be card carrying members of the ruling political party that appointed them in view of section 156(1) of the constitution, which provides that a person shall not be qualified to be appointed the chairman of INEC, if the persons is not qualified for election to the House of Representatives. When this section is read together with section 65(2) (b) - which provides that a person is not qualified for election to the House of Representatives except the candidate is, "a member of a political party and is sponsored by that party" - the effect would be that officials of INEC must be members of a political party and sponsored as such. It can then rightly be believed with certainty that INEC officials are members of the ruling party, which appointed them, given that the present state of our democratic experience does not give room for any contrary belief. As the cases would reveal, in reality, members of the current INEC do not hide the fact that they are members of the PDP.

Support for this contention could be garnered from the cases. In Abubakar v. Yar' Adua, (Note 29) the petitioner contested the presidential election on the platform of the AC; he hardly had the opportunity to campaign and prepare for the election, as INEC unilaterally disqualified him until his candidature was confirmed by the Supreme Court only four days to the election. After the election, the petitioner challenged the validity of the election and the result declared in favour of the respondent. By a split decision of three to four, the majority affirmed the validity of the election at the Supreme Court. Delivering the minority judgment, which nullified the election, Oguntade JSC lamented:

"In an election under a democratic system...the public body (INEC) organizing the election must ensure that all the political parties and their candidates are afforded equal opportunity to approach the electors with their party programmes. The public body must not show special favour or disfavour to any of the candidates." (Note 30)

The counsel of his Lordship above was not based on some abstract supposition but on the prevailing trend of bias perpetrated by INEC. In the case of INEC \& Ors v. Oshiomhole \& Ors, (Note 31) the $1^{\text {st }}$ Respondent and $2^{\text {nd }}$ appellant contested the gubernatorial election in Edo State, as the candidates of the Action Congress (AC) and the Peoples Democratic Party (PDP) respectively. Against loud protests by the electorates, INEC declared the $2^{\text {nd }}$ respondent the winner of the election. Consequently, the $1^{\text {st }}$ respondent filed a petition at the election petition tribunal, which declared him winner of the election, after recounting the votes cast in the areas represented by the results being challenged in court. The $1^{\text {st }}$ appellant (INEC), and others appealed to the Court of Appeal. Affirming the decision of the tribunal, the President of the Court of Appeal, lamented the role INEC played both during the election and in the course of litigation, and reminded INEC that it is expected to be impartial, unbiased and neutral in the performance of its duties, but that it derailed from that role in this particular case, where it "indulge[d] in filing objections to the petition and filing appeals against the Ruling and the Judgment of the Tribunal." (Note 32) 
As much as the appetite of INEC for illegality and partiality is largely insatiable, so is its ingenuity for subtle inventions and evasions towards subverting the provisions of the law in order to give its preferred political party a smooth sail to office, irrespectively of the votes of the electorates. One of its latest inventions was to illegally withhold the results of election candidates, except the candidate it prefers, is returned elected. This was exactly the antics displayed by INEC in Adams v. Umar (Note 33). Here, the court of appeal found that INEC deliberately refused to declare the results of the other candidates for the election in order to declare its "favoured one" the winner of the election. (Note 34) Another of such invention is to unlawfully disqualify opposition candidates a few hours to the commencement of voting. In INEC v. Action Congress (Note 35), INEC unlawfully disqualified the gubernatorial candidate of the AC, the strongest contender against the PDP, on the eve of the gubernatorial election in Adamawa State, and then conducted a sham election, in which it declared the PDP candidate the winner. What is even more disheartening is that the premeditated nature of this action was exposed by the fact that during the sham election, which took place, the next morning, the picture of the AC candidate, which had been printed on the ballot paper by the same INEC, was already defaced in the large volume of ballot papers supplied for the election by INEC.

The AC successfully challenged the illegal actions of INEC in court. In a unanimously judgement, the Court of Appeal condemned, in strong terms, the conduct of INEC towards the AC. Salami, JCA put it in the following words:

"The Independent National Electoral Commission is the body charged with the statutory responsibility for the conduct of elections. As its name suggests, it is expected to maintain independence or absolute neutrality. But it has unwittingly or tragically descended into the arena or fray on the side of one of the candidates, $4^{\text {th }}$ respondent. Clearly and respectfully, this is not how to tend the rope or maintain neutrality." (Note 36)

There is no gainsaying the fact that INEC is supposed to be independent, at least, for its name's sake. Unfortunately, the contrary is the case; a situation which is strongly suggestive of a political affinity between INEC and a political clique, and which affinity has robbed it of its true independence, thereby making it impossible to assert its independence in the performance of its functions.

\subsection{Upholding the Rule of Law}

It is incumbent on INEC, as an organisation established by law to uphold and defend the law at all times without fear or favour, affection or ill-will. In every crises or even mere arguments, INEC ought to be spotted on the right side of the law. Unfortunately, the Nigerian courts, even up to the Supreme Court, have on several occasions deprecated the penchant of INEC for the strangulation of the very law that set it up. In doing this the courts have often used very strong words; the courts have referred to INEC as 'lawless', 'irresponsible,' 'a meddler',(Note 37) among others.

In many ways than could be counted on the finger tip, INEC has displayed its propensity for lawlessness both in the discharge of its duties (as already clearly shown above) and in its conduct towards the judiciary. Apart from its record of disobeying court orders, INEC is also notorious for appealing court decisions, which are unfavourable to its preferred candidates, at the expense of the tax payer. In Haruna v. Modibbo, (Note 38) INEC v. Action Congress, (Note 39) INEC \& Ors v. Oshiomhole \& Ors, (Note 40) among others, the courts wondered what the interest of INEC was in the cases, that it was INEC which decided to appeal the judgements which were unfavourable to a particular political party. This goes to strengthen the suggestion of an unholy affinity earlier raised above. (Note 41)

Of particular importance here is A. G Fed \& Ors v. Abubakar \& Ors (Note 42), a case which arose from the strained relationship between former President Olusegun Obasanjo and his Vice President, Alhaji Atiku Abubakar - who were both elected to that office on the platform of the PDP first in 1999 and in 2003 for a second term in office - and the consequential suspension and eventual expulsion of the latter from the PDP. Following his expulsion, the latter joined the Action Congress (AC), which nominated him their candidate for the presidential election. As a result, Chief Obasanjo and the PDP unilaterally declared the office of the Vice President vacant. The Vice President, Alhaji Atiku Abubakar, as plaintiff $\left(1^{\text {st }}\right.$ respondent at the Supreme Court $)$ brought an action at the Court of Appeal (in exercise of its original jurisdiction under section 239(1) of the Constitution of the Federal Republic of Nigeria 1999) challenging his purported removal, as Vice President. The Court of Appeal found for the plaintiff to the effect that his defection from the PDP did not affect his position as the Vice President of Nigeria. The Attorney-General of the Federation, the Inspector General of Police and INEC (which was the $6^{\text {th }}$ defendant at the Court of Appeal), were dissatisfied with the Court of Appeal judgment and appealed to the Supreme Court. 
While unanimously dismissing the appellants appeal, the Supreme Court, was amazed at the decision of INEC to appeal the judgment, when as a Shepherd of a good democratic order, INEC ought not to be spotted on the other side of the divide. The court noted with dismay that "the $2^{\text {nd }}$ and $3^{\text {rd }}$ appellants in this matter are the Inspector General of Police and the Independent National Electoral Commission (INEC)" (Note 43). The apex court continued: "...Also the Independent National Electoral Commission (INEC) by its statutory existence is an independent body with constitutional powers to conduct elections in Nigeria. It must not only be an umpire, it must be seen in the eyes of reasonable men, to be an umpire in the conduct of an election. INEC must never by act of omission or commission place itself in a position where imputations of partiality in favour of one party against another one will be leveled against it. Neutrality must be the watch word of the body - it must always remain fair and focused. ...the Inspector General of Police and the Independent National Electoral Commission, INEC, appeal in this case is very much in bad taste. They have both thrown the quality of impartiality and fairness which they represent to the winds. Their acts are capable of eroding the public confidence in them. Unknown to them, they may be said, by the public, to be biased and therefore not worthy to be regarded as impartial umpires. This trend must not repeat itself for the good of the nation. It is a sour taste." (Note 44)

What is even more, and indeed the most unfortunate is that INEC is in the perpetual habit of observing court judgements in the breach. It has shown itself unwilling to obey the ordinary courts of the realm. Once again, the cases supporting this view are commonplace. In Onyekweli v. INEC, (Note 45) the Court of Appeal frowned at the fact that, "the respondent [INEC] in spite of a pending petition blatantly refused to obey the rule of law and gave a certificate of return to someone who did not contest the election. This was a dastardly and altogether condemnable act on the part of INEC. It was totally unjustifiable. It smacks of total recklessness and disregard of the judicial process. INEC turned around in the face of pending litigation to give the certificate to another person. The executive arm of government as represented by INEC should not be allowed to get away with this rape, yea, violation of the judicial process. INEC, a supposedly "independent" umpire in a democratic process has shown that in this case it was not independent. It illegally connived from the word go to deprive a successful litigant of the fruit of his judgment..."

In Obi v. INEC (Note 46) the appellant contested the governorship seat for Anambra State in April 2003 general elections on the platform of All Progressive Grand Alliance (APGA). After the election INEC declared his opponent of the PDP, Dr. Chris Ngige, the winner of the election. The appellant filed a petition at the election tribunal challenging the declaration of his opponent as the winner by INEC. He won the case and was sworn into office in 2006, three years after he won the election, and one year to the next general election.

The appellant brought this action, when INEC started making preparations for election to the governorship seat of Anambra state, barely one year after he took his oath of office. While the action was pending in court, INEC went ahead and conducted election into the seat and declared the candidate of the PDP (Dr. Andy Uba), the winner of the election. Nullifying the election conducted by INEC, and declaring that the seat of the appellant will not be vacant until the effluxion of four years from the date he took his oath of office, as prescribed by the constitution, the Justices of the Supreme Court were unanimous in condemning the conduct of election in the state by INEC, while proceedings were pending in court. Aderemi JSC remarked:

"I need to add that as at $14^{\text {th }}$ April, 2007 when the $1^{\text {st }}$ respondent, INEC was conducting gubernatorial election in Anambra State, the seat of the governor of that state was not vacant. That election was a wasteful and unnecessary exercise. The $1^{\text {st }}$ respondent was aware at that time that the appellant was in court pursuing his legal rights. A body that has respect for the rule of law, which INEC ought to be, would have waited for the outcome of court proceedings; particularly when it was aware of it." (Note 47)

The courts are not alone in the condemnation of the dealings of INEC, as there is a general consensus that the present INEC is leading the current democratic experience on the path of destruction. From the academia to the civil societies and international observers the verdict is the same.

From the international perspective, the Commonwealth Observer Group Report on the April 2007 elections in Nigeria found serious deficiencies in the electoral system and stated that Nigeria has fallen short of the democratic standards. Of the three areas of concern mentioned by the group two were (i) "the readiness, efficiency and transparency of INEC" and (ii) "the abuse and influence of incumbency on INEC" (Note 48). On its part, the European Union noted that the 2007 elections conducted by INEC fell, "far short of basic international and regional standards for democratic elections and ... cannot be considered to have been credible." (Note 49)

The report of the National Democratic Institute observer's on the election was of the same tenor as the above reports. The report regretted that: 
"The electoral process has failed the Nigerian people... Regrettably, the 2007 polls represent a step backward in the conduct of elections in Nigeria .... The serious flaws witnessed during this electoral process threaten to further erode citizen confidence in the country's democratic institutions." (Note 50)

This sentiment is equally shared by other election observers and public commentators alike. The Report of the International Organization for Sustainable Development Election Observer Mission, which observed the April 2007 Elections, (Note 51) indicted INEC for inter alia: (a) Compilation of fictitious names on voters register; (b) Falsification of election results; (c) Illegal printing of forms used for collation and declaration of election results; (d) Deliberate refusal to supply election materials to certain areas; (e) announcing results in places where no elections were held; (f) Box switching and inflation of figures. Having so observed the mission remarked:

"Given the observations and analysis set out in this brief report, it would not be possible to state that the election, both on the $14^{\text {th }}$ and the $21^{\text {st, }}$ were 'free and fair'. ... Much was and continues to be said about the conduct if INEC, whether or not, for instance, the confusion was the result of poor planning or orchestrated incompetence meant to generate the result required by the ruling party." (Note 52)

The findings of the Transition Monitoring Group (TMG), is in tandem with the views expressed above. The group observed that, "...the irregularities were so numerous and so far reaching that 'the election was a charade and did not meet the standards required for democratic elections. ...The Electoral Commission (INEC) 'failed willfully in their responsibility to conduct free, fair and credible elections'...We call on the international community not to recognize these discredited elections and not to confer legitimacy on any government that emerges there from..." (Note 53)

\section{What is wrong with INEC?}

Public organizations are legal entities. Such organizations are established by law and operate within the framework of the law. This simply means that the administrators of such organizations must be guided by the provisions of existing laws in the performance of their duties. (Note 54) Two major indices can be garnered from the above statement of fact: public organizations, having been established by law, must carry out their functions in tandem with the dictates of their enabling laws in order to meet the object for which they were established; and as a corollary, they must be properly guided by law in order to ensure that they do not derail from their legal path.

Considering what has been said above, it is obvious that INEC has since abandoned these tenets and instead crossed over to the side of illegality and immorality. The duty on us now is how to redeem the institution from the iron claws that holds it bound and thus redeem the electoral process in order to install the needed representative democracy in Nigeria. We cannot do this except we understand, or perhaps, conjecture on why INEC has never been able to live up to expectations. We can identify what is wrong with INEC under two broad headings - (a) defects in law; (b) Bad politics

\subsection{Defects in Law}

As already stated above, the existence and activities of INEC are regulated by the Constitution and the Electoral Act. These documents contain provisions on the establishment of INEC, the appointment of its officers, funding, among others. We shall concentrate on appointment and funding.

\subsubsection{Legal Defects in the Appointment of INEC Officers -}

INEC, as an artificial body, though a persons in the eyes of the law, is not capable of chatting a course for itself in its abstraction. Of course, "it has no soul to be damned and body to be kicked"; (Note 55) its directing will and mind can only be found in the officers - the alta ego, who run the affairs of the institution on a daily basis. It thus follows that it will be difficult, if not impossible, for INEC to function effectively, if the provisions of the law on the appointment of its officers are flawed. As already pointed out above, the crafters of the constitution may have perhaps erroneously, accidentally or mischievously allowed the criteria for qualification for appointment as INEC chairmen to be tied to being a member of a political party. That singular provision has been a major disservice to Nigeria and Nigerians, and indeed the albatross of INEC since 1999. Members of INEC having expectedly been appointed from the ruling political party, as required by the constitution, naturally see INEC as an extension of that particular party. INEC is thus, not only subjected to the whims and caprices of the President but also to the structure and political road map of the ruling party, to the detriment of all the other political parties and the electorates, who have had to put up with the vicious consequences of the provision.

\subsubsection{Legal Defects in Funding}

Closely related to the above is the fact that the funding of INEC is tied to the whims and caprices of the executive, to which INEC has to go cap in hand for its funding like every other department and ministry of 
government. There are often insinuations during run up to elections that INEC budgetary allocations are being withheld by the executive. This is complicated by the failure, or outright refusal of the relevant agencies of government to hold INEC officials accountable for budgetary allocations thus making it impossible to know what monies it actually received in budgetary allocations and donations. For instance, despite the huge budgetary allocation for the 2007 elections, the elections were characterized by massive logistic failures, such as shortage of ballot papers, and data capture machines, among others. This situation has encouraged corruption within the organization and thus contributed to the problem.

The current provisions of the law which leaves enormous financial and political power in the President in the appointment of the INEC chairman and other key officers of the organization, no doubt exposes INEC to the temptation of being influenced by superior authorities thereby denying INEC its independence. The cliché that "he who pays the piper dictates the tune" readily comes to mind at this point. This, no doubt, makes it difficult for INEC to be firm in the face of presidential temptation.

\subsection{Bad Politics}

The common slogans of Nigerian politicians are, "do or die" elections; "there are no morality in politics", and so on and so forth. These words, which reflect their belief, show that the Nigerian politician does not understand that elections have to be won and lost on the basis of ballot papers. Hence, they mortgage every sense of sanctity in their bid to gain a fraudulent advantage over their opponents; both politicians in government and opposition politicians alike take advantage of the willing agents at their disposal to outdo the other. Due to the fact that these politicians wield enormous resources, the willing voters and all willing agencies of government, including INEC and the police, fall prey to their wealth and influence while the unwilling become their victims. Politicians have been accused of inciting ethnic and religious violence as means of acquiring political power and or maintaining same. What could be more serious than the outcry of an erudite Justice of the Supreme Court in Buhari v. INEC \& Ors, that "the way politics in this country is played frightens me every dawning day. It is a fight to finish affair. Nobody accepts defeat at the polls...."(Note 56)

What is even more dangerous is that the political parties lack a clear cut manifesto, which could be presented to the electorates as alternatives. The implication is that all the fifty political parties, more or less, present the same manifestos. Consequently, party programmes are overshadowed by the integrity or the perceived integrity of individuals; the electorates are compelled to choose between individuals rather than political parties. When such individuals are not in the good books of the leadership of their political party, and is thus schemed out of the race by undemocratic means, the individual either goes to court or easily joins another political party (since the manifestos are hardly different anyway), where he is offered the nomination denied him by his original party on a platter of gold. The cases of INEC v. AC (Note 57) and Amaechi v. INEC, (Note 58) testify to the fact that whenever this occurs, INEC, having failed to regulate the process from the outset, is boxed to the receiving end, even as it spends quality time and resources defending law suits that would have been avoided, if politicians would abide by the set rules of the game. Consequently it loses concentration and its grip on the political system, which is thus subjected to public opinion and more frequently the court; an institution, which in an ideal political environment, is less suited to be invited into the arena of profound political issues. The problem of INEC is largely the problem of politics and lack of democratic culture; the defects in the law, notwithstanding, the more political parties instill discipline and transparency in the process of nomination of their electoral candidates and run the parties on the basis of ideological conviction, the less the intra party crises INEC will have to tackle and the less the court cases it will have to defend.

\section{Conclusion}

To resolve the numerous problems facing INEC, as an institution, the law has to be called in aid. The law maker must anticipate, as would those who are bent on circumventing its provisions, the possible ways in which it may be circumvented and provide necessary safeguards. For there is no alternative to the view that:

"The beauty of law in a civilized society is that it owes its respect and due observance to the society. It should be progressive and act as a catalyst to social engineering. Where it relies on mere technicality or out-moded or incomprehensive procedures and immerses itself in a jacket of hotchpotch legalism that is not in tune with the times, it becomes anachronistic and it destroys or desecrates the temple of justice it stands on." (Note 59)

This perhaps is why all eyes are on the National Assembly to amend existing laws in the light of the manifest defects which have plagued the electoral process since 1999. The difficulty of legislative intervention is underscored by the fact that what is required is a holistic legislative overhaul of the entire existing laws, which invariably requires the cumbersome process of constitution amendment. Accordingly, sections 3-6 of the Electoral Act must be amended to free the finances of INEC from the control of the executive by charging it 
upon the consolidated revenue fund of the federation under section 81 of the constitution. While strengthening the financial base of INEC, a strong regime of accountability should be put in place to check the misuse - such as expending the fund on filing unnecessary appeals - and misappropriation of the funds by officials. The National Assembly should be saddled with the responsibility of appointing independent financial auditors to audit the finances of INEC and submit its report to a joint session of the Assembly after each general election.

Also, sections 154(1), 156(1), and section 14 of item F part 1 of the Third Schedule to the Constitution, relating to appointment of INEC officers, must be amended. In view of the mischief being created by section 156(1), its current provision that INEC Chairman must be a member of a political party must be reversed to provide for a non partisan INEC chairman and officers. In addition, the recommendation of the Hon. Justice Uwais' Committee on Electoral Reform should be partly adopted and incorporated in the Electoral Act. The proposal of the Committee that nominees for the INEC chairman should be screened by the National Judicial Council (NJC) is commendable, but rather than forward the nominees to the Council of States (made up of all governors and chaired by the President) to select the candidate of its choice from the list presented by NJC before forwarding same to the Senate for confirmation (Note 60), as proposed by the Committee, we would rather that the list be forwarded to a panel made up of representatives of all the political parties, for a consensus selection of the name to be sent to the Senate. This will build confidence in the system and create a collective responsibility for all the political parties. It is germane, at this juncture to state that due to the cumbersome process of constitutional amendment in comparison with the ever changing political atmosphere, it is unsuitable to make detailed provisions on INEC in the constitution. It suffices for the constitution to establish INEC, while the details should be provided in the Electoral Act, for ease of amendment, when the need arises.

It is not enough to make INEC officials take oath of neutrality, (Note 61) when necessary safeguards are not put in place to ensure that the members are able to resist incumbency pressure and corruption. Very strict penalties should be provided. It is no less treasonable for an officer or a group of officers to connive with a cabal to steal power from the people, whose taxes pay their bills. Therefore, any INEC officer, who indulges in such connivance, should be tried for treason. The enormity of the consequences of such official treason can only be seen in terms of the loss of lives and properties that have followed the declaration by INEC of results, which the electorates did not believe reflected their votes, as well as the irresponsive leadership such diabolic acts have imposed on the people at all levels since 1999. As the 2011 general elections approach, there can be no better counsel than the judicial one freely offered INEC by Sankey, JCA, that:

"INEC and all its officials acting on its behalf, must take extra and special care to scrupulously adhere to all the provisions of the law that pertains to elections. Transparency must be the watchword to provide a level playing field for all comers. Ours is a bourgeoning democracy and nothing outward should be done to destabilize this upward and aggressive progression of the nation to join the comity of nations in the so-called first world. All must stand up to be counted in this phenomenal and formidable but very worthy effort." (Note 62)

But it will not be enough to amend the laws and sit back wishing that INEC obeys the law, we must all play our parts. Those who are saddled with the responsibility of seeing that the laws are obeyed must also be empowered to perform their duties. Experience has shown that it is not enough to amend laws; there must be strong incentives for obeying the law and penalties for disobeying same. There must be a common consciousness in the voters, the political parties, the press, the civil society organizations and all the arms of government, on the inevitability of the obedience of law to the emergence of an egalitarian society and indeed an electoral system that will be fair to all. Such consciousness seems largely lacking today on the part of the government, the politicians and their political parties. It is only with the active or tacit support of government that INEC, the politicians and their political parties would drive the political system, as far as they have, on the path of ignominy. Indeed all the political parties are guilty of this. It is only a question of degree, measured in terms of how much money and executive power, any one party has to outdo the others.

In the final analysis, in all the misdemeanor of INEC, the chief legal officer of the federation, the Attorney-General of the federation, who is saddled with the responsibility of advising the federal government and its agencies or parastatals, can never be blameless. As an agency of the federal government,(Note 63) the duty to give INEC proper legal direction falls squarely on the Federal Attorney-General, as the public defender of the law (Note 64). Although this is not the right place to discuss the role of the office of the Attorney-General (during the relevant period, particularly, between 2006-2009) in the desecration of the electoral process, the fact that there is no evidence in any court of law, where the Attorney-General has challenged the illegal actions of INEC speaks volumes. On this score, we must not omit reference to section 150 , which combines the office of the chief legal officer - the Attorney-General with a political office - Minister of Justice. As it stands, the section fuses both a career position and a political office in one person, who being an appointee of the president and a 
politician cannot escape being partisan. To make the office of the Attorney-General effective, as the guardian of the law, section 150 must be amended to stripe the Attorney-General of its ministerial portfolio, while the appointment into the office should be done from career legal practitioners from the Federal Ministry of Justice. The office should not be tied to the life of the president in office. That the possibility of separating these offices is even envisaged by the constitution, is clear from section 174, which while providing for duties of the attorney-general, as a legal officer, refrained from mentioning "minister of justice", but "attorney general" was used throughout the section. It is only such an independent attorney general that will rise up to the occasion to challenge breaches of the law, even by the executive and provide legal lifeline to institutions in times of official decadence, as is the case with the present INEC.

It is our candid view that no legal innovation will work except stiff penalties are proclaimed and enforced against those who contravene the law. Despite the massive electoral offences (Note 65) revealed in the various election petition cases decided by the courts, not even a politician or a member of INEC has been punished for his or her misdeeds. This encourages impunity and sends a wrong signal to the people.

As we approach another round of elections in 2010 (Note 66) and 2011, the time to say "no" to ballot coup and its attendant loss of life and property is now; a good majority of the Nigerian voter (Note 67) and indeed the judiciary (Note 68) have shown the way, the politicians and security agencies must follow suit, as the problem is not wholly that of INEC, as an institution, but of its officials; the political allies of INEC officials and their agents - the police and sometimes, the military. INEC must be compelled to stop playing the wolf.

\section{References}

Report of the International Organisation for Sustainable Development Election Observer Mission, which observed the April 2007 Elections (online) http://www.iosd.org/inecreport.pdf.

The Guardian. (2007). (Nigeria) Newspapers of Wednesday, May 30.

Vanguard Newspaper of October 8, 2009

Vanguard Newspaper of October 3, 2009

The Guardian. (2007). (Nigeria) Newspaper of Tuesday, June 5.

The Guardian. (2007). (Nigeria) Newspapers of Tuesday, April 24.

A.O Enabulele. (2009). 'Substitution of Electoral Candidates in Nigeria: Whose Ox is Gored Anyway?' in Prof. L.A Atsegbua (ed.) Electoral Law in Nigeria 58.

A.O. Enabulele. (2008). 'Disqualification of Election Candidates in Nigeria: Some Reflections' 34(3) Commonwealth Law Bulletin 561

BBC News. (2007). (Online) http://www.iri.org/newsarchive/04-23-BBCNews-Nigeria.asp

Umukoro, N. (2009). Public Administration and Development in Nigeria, (Ambik, Benin City) 78

Coffee J.C. (1981). 'No Soul to Damn, No Body to Kick: An Unscandalised Inquiry into the Problem of Corporate Punishment' 79 Michigan Law Rev.

The Vanguard Newspapers (online) www.vanguardngr.com/2009/10/10/uwais-faults-yaradua-on-electoral-bill. accessed on 20/10/2009.
Abbreviations:
NWLR - Nigerian Weekly Law Reports
LRCN - Law Reports of Courts of Nigeria
FWLR - Federation Weekly Law Reports
JSC - Justice of the Supreme Court
JCA - Justice of the Court of Appeal

\section{Notes}

Note 1. In his inaugural speech delivered to the Nation on May 29, 2007, President Yar'Adua stated "we acknowledge that our elections had some shortcomings .... Accordingly, I will set up a panel to examine the entire electoral process with a view to ensuring that we raise the quality and standard of our general elections, and thereby deepen our democracy". See The Guardian Newspapers of Wednesday, May 30, 2007, at pp. 1-2 and particularly at p. 9 . 
Note 2. In order to deepen the crises in the party and cause confusion within that party, which controls the government in Anambra state and stand tall in the ranking of political parties likely to win the governorship election, INEC, which all along the crises within the party had related with Victor Umeh as the chairman of the party in line with the judgements of the courts and the report of a Committee set up by INEC itself, suddenly made a u-turn to start dealing with Chekwas Okorie, as the chairman of the party and hurriedly issued him the nomination forms for the governorship election in the state with a view to tactically excluding the incumbent governor from being nominated. Meanwhile, Chekwas Okorie had been expelled from the party, as affirmed by two judgements of competent courts of the realm; one of which was filed by Chekwas Okorie himself. See the Guardian Newspaper of April 17, 2008. The court emphatically stated that Okorie and his cohorts, "having been validly expelled from the party, have no right to subscribe the name... the expulsion of the $2^{\text {nd }}$ plaintiff (Okorie) and others, stands." The strange twists to the whole shameful events is that while both INEC and Chekwas Okorie denied the existence of any judgement of the court on the point, they are in the Court of Appeal in Abuja, appealing the said judgements which they have failed to comply with. In a preliminary hearing the Court of Appeal has held that the said judgements are valid and binding on them, until the Court of Appeal finds otherwise and ordered them to obey same. See the Vanguard Newspaper of October 8, 2009, p. 1. Time shall tell whether INEC officers and their co-travelers will obey the Court of Appeal. It remains to be said that as Anambra State - one of the 36 states of the Federation, - prepares for its governorship elections in 2010, all right thinking Nigerians have been drawing the attention of the federal government - which in any case, is actually the masquerade in INEC - to the dangers of the role being played by INEC in the leadership crises in APGA. It is also important to remember at this point that Anambra state is having its governorship election in 2010 (ahead of the 2011 general elections), due to the misdeed of the same INEC, which had declared victory for its preferred candidate of the ruling political party (the PDP), Dr. Chris Ngige, who spent three years out of a four year tenure as the governor of the State before the courts concluded Peter Obi's case and declared him winner of the election. It is also instructive that the same unrepentant INEC went ahead to conduct election into the same office, less than a year after Peter Obi was sworn into office, in violation of a subsisting court order. This illegality continued until, the Supreme Court declared the action of INEC unconstitutional and ipso facto ordered Peter Obi to be restored to his office - Obi v. INEC [2007] 11 NWLR (Pt. 1046) 560, discussed in p. 22 infra. It is also pertinent to state that the legal dust raised by the conduct of INEC is still on, as Dr. Andy Uba, the PDP candidate, who was declared the winner of the election and sworn in as governor before the Supreme Court affirmed the continuation of the tenure of Peter Obi, is currently in the Court of Appeal, asking the court to declare him the governor- in -waiting and swear him in as the next governor of the state after the tenure of Peter Obi in 2010. See the Vanguard Newspaper of October 3, 2009 for a detailed over view of the crises in Anambra State.

Note 3. [1999] 6 NWLR (Pt. 606) 283.

Note 4. [2003] 17 NWLR (Pt. 850) 423

Note 5. (2009) 166 LRCN 1

Note 6. (2009) 167 LRCN 1. The election was nullified by Mukhtar, Ogundare and Onnoghen JJSC.

Note 7.To mention gubernatorial election results alone, the court nullified Edo, Ekiti, Ondo, Kogi, Rivers, Anambra, Cross River, Adamawa and Bayelsa States.

Note 8. See an Article written by Don Mckinnon, a Commonwealth Secretary-General, titled "What now for Democracy in Nigeria", in the Guardian Newspaper of Tuesday, June 5, 2007 at p. 79.

Note 9. The Guardian Newspapers of Tuesday, April 24, 2007 at p.10

Note 10. Ibid

Note 11. See INEC v. Oshiomhole (2009) 174 LRCN 178; Nwoga v. Benjamin \& Ors. [2009] 5 NWLR (Pt. 1133) 152; Odali v. Ahmadu [1999] 5 NWLR (Pt .60) 22; Aondoakaa v. Ajo [1999] 5 NWLR (Pt. 602) 206; Balewa v. Muazu [1999] 5 NWLR (Pt. 604) 636, etc

Note 12. See Amaechi v. INEC (2008) 158 LRCN 1; Odedo v. INEC (2008) 162 LRCN 1; Wike v. Muazu [1999] 4 NWLR (Pt. 600) 618; Tsoho v. Yahaya [1999] 4 NWLR (Pt. 600) 658, etc.

Note 13. Although section 154(1) of the constitution made the appointment of the chairman of INEC subject to the ratification of the Senate, the Senate has on many occasions showed that it is incapable of providing the checks envisaged by the section. The practice since 1999, particularly in the current era, has been for the executive to appoint and Senate rubber stamp. Appointees are usually requested to take a bow to the cheers of the Senators. Consequently, appointments seem to be the exclusive prerogatives of the executive, whether or not 
the constitution requires the ratification of the appointment by the Senate. The seat of INEC officials is even more so, given the fact that the Senate is dominated by the ruling PDP. We also must not lose sight of section 14 of Item F Part 1 of the Third Schedule to the Constitution, which gives the president the sole power to appoint Resident Electoral Commissioners for all the States of the Federation and the Federal Capital Territory.

Note 14. Sections 3- 6 of the Electoral Act, 2006

Note 15. Section 158(1) of the Constitution

Note 16. This constitutional power has been reinforced in a number of cases - INEC v. Ray [2004] 14 NWLR (Pt. 892) 92; Buhari v. Obasanjo [2003] 17 NWLR (Pt. 850) 423, among others.

Note 17 INEC v. Oshiomhole [2009] 4 NWLR (Pt. 1132) 607,662

Note 18 This phrase assumes much more than a people being governed by foreigners; it also extends to a situation, where a few individuals hijack the electoral mechanism and thus manipulate the people and steal their votes. A people who are governed by a government that stole its way into office through rigging and malpractice cannot, to all intent and purposes, be said to be governing itself. Such a people suffer from elitist colonialism.

Note 19. See A.O. Enabulele, "Disqualification of Election Candidates in Nigeria: Some Reflections" (2008) 34(3) Commonwealth Law Bulletin 561(discussing instances of unilateral disqualification of candidates by INEC in violation of the provisions of the Electoral Act.)

Note 20. See sections 32 and 34 of the Electoral Act. These provisions have been exhaustively discussed in A.O Enabulele, "Substitution of Electoral Candidates in Nigeria: Whose Ox is Gored Anyway?" in Prof. L.A Atsegbua (ed.) Electoral Law in Nigeria (2009) 58.

Note 21. [2004] 10 NWLR (Pt. 881) 224 at 260.

Note 22. Ibid at p. 293.

Note 23. [2008] 14 NWLR (Pt. 1107) 317; also in Ojo v. INEC [2008] 13 NWLR (Pt. 1105) 577, the Court of Appeal frowned at the "lawlessness of INEC", and remarked that the facts leading to the case, would not have occurred, "if INEC was truly independent" id at 615

Note 24. Ibid at 366

Note 25. Ibid at pp.364-5

Note 26. (2008)158 LRCN 1

Note 27. Ibid at p. 246

Note 28. Ibid at pp 249-250. The court could not contain its dismay, when in Odedo v. INEC (2008) 162 LRCN 1 - a case which bears similar facts with Amaechi's case, and which also concerned the PDP - it was established in evidence that INEC acted in similar manner. In reversing the lawlessness of INEC, the Supreme Court variously described it as a lawless body that has no regards for the rule of law. (pp. 68-9)

Note 29. Abubakar v. Yar'Adua, supra

Note 30. Ibid at pp.202-3.

Note 31. (2009) 174 LRCN 178.

Note 32. Ibid at p.230, per Abdullahi, PCA,

Note 33. [2009] 5 NWLR (Pt.1133) 41.

Note 34. Ibid at pp.98, 147 and 150. This situation was deprecated by all the three Justices of the Court of Appeal, who heard the case.

Note 35. [2009] 2 NWLR (Pt.1126) 525.

Note 36. Ibid at p.611

Note 37. INEC v. AC [2009] 2 NWLR (Pt. 1126) 525 at 611

Note 38. [2004] 16 NWLR (Pt.900) 487

Note 39. Supra

Note 40. Supra

Note 41. Also see Amaechi v. INEC (2008) 158 LRCN 1, at 88.

Note 42. (2007) 150 LRCN 1632 
Note 43. Per Aderemi JSC at 1789

Note 44. Ibid, at 1789 - 1790

Note 45. Supra at p. 366

Note 46. [2007] 11 NWLR (Pt. 1046) 560

Note 47. Ibid at page 645; also see Oguntade J.S.C., at 672, Chukwuma-Eneh, J.S.C., at 694

Note 48. Don Mckinnon 'What is now for Democracy in Nigeria', The Guardian Newspaper, Tuesday, June 5, 2007, p. 79 (Don Mckinnon is a Commonwealth Secretary General)

Note 49. Ibid

Note 50. Ibid

Note 51. Presented to Prof. Maurice Iwu on June 20, 2007 (online) http://www.iosd.org/inecreport.pdf accessed on $2 / 12 / 2008$

Note 52. Ibid at page 10

Note 53. (Online) http://www.iri.org/newsarchive/2007-04-23-BBCNews-Nigeria.asp - accessed on 28/7/2009.

Note 54. Umukoro, N., Public Administration and Development in Nigeria, (Ambik, Benin City, 2009) 78

Note 55. To borrow the words of Baron Thurlow, quoted in coffee J.C 'No Soul to Damn, No Body to Kick: An Unscandalised Inquiry into the Problem of Corporate Punishment' 79 Michigan Law Rev, (1981) p. 386

Note 56. Supra at p. 171

Note 57. Supra

Note 58. Supra

Note 59. Per Pats-Acholonu, JSC, in Buhari v. Obasanjo (2004) 1 EPR 160, 214

Note 60. www.vanguardngr.com/2009/10/10/uwais-faults-yaradua-on-electoral-bill. - accessed on 20/10/2009. It is believed that such arrangements will increase the independence of INEC. The seriousness of the government towards genuine electoral reforms however remains to be seen even as the white paper on the report released by the Electoral Reform Committee, which the government eagerly set up, is yet to be released several months after the report was submitted. This is not to mention the controversy trailing the alleged alteration of the report by the executive.

Note 61 . Section 29 of the Electoral Act. This sentiment is commonly shared by all the international bodies which monitored the 2007 elections. See Don Mckinnon, supra

Note 62. Adams v. Umar [2009] 5 NWLR (Pt.1133) 41 at 135

Note 63. The courts have severally declared INEC as an agency of the Federal Government. See University of Abuja v. Ologe [1999] 4 NWLR (Pt. 445) 706 at 725, Obasanya v. Babafemi (2000) FWLR (Pt. 15) 2585 at 2606-2607, AD v. INEC (2004) 1 EPR 288 at 303.

Note 64. In A-G., Fed v. ANPP [2003]18 NWLR (Pt. 851) 282, the Supreme Court held that the Attorney General of the Federation, as the chief law officer should be interested in any question relating to the validity and or the correct interpretation of the laws of the federation, including the constitution. If the attorney general has lived up to its responsibilities, cases like Attorney General of the Federation v. Atiku, AC v. INEC, would not have arisen at all.

Note 65. These offences are contained in part VIII of the Electoral Act.

Note 66. In Anambra State and other States that will conduct their elections at different times

Note 67 . Whose resilience and commitment to democratic governance was highly commended by the foreign election monitors

Note 68. Indeed the judiciary has made it clear both in words and in deeds that it will not support, "the novel style of INEC to engage in blatant illegality .... If an organ of the executive like INEC decides to engage in lawlessness, we [the judiciary] shall not lend ourselves to be used as a tool for the prosecution of their illegality" - Onyekweli v. INEC [2008] 14 NWLR (Pt.1107) 317 at 372. 